\title{
Н. ДАВИДЮК
}

Natalia Davyduk

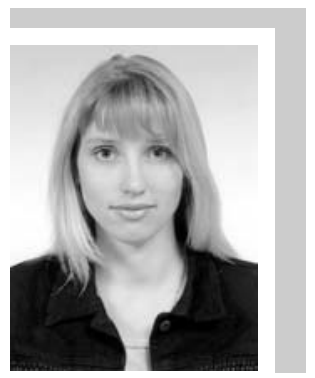

\section{ТИПОВІ ПРИЧИНИ ФОРМУВАННЯ КОНФЛІКТНИХ ВЗАЕМИН У ПОДРУЖНІЙ ДІАДІ}

Постановка проблеми. Вивчення актуального стану розвитку сім'ї дає можливість виокремити тенденцію до певної деформації шлюбно-сімейних цінностей, стосунків, що призводить до зростання числа розлучень, збільшення кількості людей, які не бажають вступати до шлюбу, а надають перевагу колегіальним (громадянським) шлюбам, не беручи на себе певні обов'язки та відповідальність за довготривалі взаємини. Збільшується чисельність подружніх пар, які розлучаються. За статистичними даними $50 \%$ перших шлюбів закінчуються розлученням, приблизно $80 \%$ розведених чоловіків і жінок знову одружуються, причому близько $60 \%$ повторних шлюбів також розпадаються.

Багато вчених - соціологів, психологів вважають, що конфлікти у сім'ї це показник серйозних розбіжностей між членами сім’ї, в основі яких лежить несумісність їхніх поглядів, інтересів чи потреб. Конфлікти ведуть до дисфункціональності сім'ї. Партнери з дисфункціональної сім'ї нездатні задовольняти потреби один одного в особистісному та духовному зростанні.

Метою цієї статті є виокремлення типових причин формування конфліктних взаємин у подружній діаді на основі аналізу психологічних досліджень сім'ї.

Причини конфліктів у сім'ях описані багатьма авторами і $є$ дуже різноманітними. Спробуємо систематизувати їх, спираючись на працю В. А. Семиченко, яка виокремлює такі головні причини сімейних конфліктів:

- одностороннє або взаємне розчарування подружжя одне в одному, взаємне охолодження і відчуження, негативне сприйняття дій партнера;

- маніпулювання 3 метою домогтися однозначного домінування, підкорити собі партнера, перехопити ініціативу у змаганні за лідерство; 
перенесення на партнера роздратування, нагромадженого в іншій сфері життя;

- відмінності в системі домінуючих (життєво важливих) потреб подружжЯ [8].

В. А. Сисенко, вивчаючи конфлікти в сім'ях, дійшов висновку, що вони базуються на:

- незадоволенні сексуальнихпотреб;

- незадоволенні потреби у цінності та значущості власного "Я" (неповага почуття власної гідності партнера, образи, постійна критика);

- незадоволеності потреби одного чи обох членів подружжя у позитивних емоціях;

- $\quad$ пристрасті одного з подружжя до алкогольних напоїв, азартних ігор, які призводять до великих витрат грошей;

- фінансових розбіжностях членів подружжя;

- незадоволеності потреби у взаємодопомозі, взаємопідтримці.

С. В. Ковальов, вивчаючи подружні взаємини у молодих сім'ях, як одну 3 головних причини подружніх конфліктів виокремив невідповідність реальних та ідеальних уявлень про свого партнера.

Ю. Є. Альошина та І. Ю. Борисов послуговуються у своєму дослідженні таким поняттям, як “статево-рольова диференціація”, що є комплексним показником, який враховує як реальний розподіл ролей у сім’ї, так і ставлення до нього кожного $з$ подружжя.

Статево-рольова диференціація визначається на основі таких характеристик:

1. Уявлення подружжя про ролі чоловіка та жінки (статево-рольові установКИ);

2. Уявлення подружжя про розподіл ролей у сім'ї (приватні статеворольові установки);

3. Рольова поведінка подружжя (реальний розподіл ролей);
4. Статева ідентичність (фемінність-маскулинність як характеристики кожного з подружжя).

Чітка статево-рольова диференціація сприяє звуженню кола обов'язків кожного з партнерів, що дає змогу їм бути більшою мірою включеними в реалізацію завдань та функцій, які перед ними безпосередньо стоять. Подібна диференціація дозволяє парі в цілому більш успішно вирішувати проблеми, справлятися з великою кількістю завдань, внаслідок чого підвищується задоволеність шлюбом. Водночас збереження жорсткої диференціації, коли необхідність у ній вже відпала (сім'я повністю адаптувалася до ситуації чи проблемність її зменшилася), навпаки, може призводити до зниження задоволеності шлюбом [2].

Реалізація сімейних функцій безпосередньо впливає на характер подружніх взаємин. Н. Н. Обозов та А. Н. Обозова змістом сімейно-рольової сфери подружніх відносин вважають співробітництво шлюбних партнерів при реалізації сімейних функцій. Функції сім'ї зумовлені розвитком суспільства, вони є історично змінними і тому в часі змінюються ролі чоловіка та жінки в сім’ї, всього устрою сім’ї [6].

Для сучасної сім'ї характерні такі функції:

- народження та початкова соціалізація дітей;

- економічна підтримка непрацездатних дітей;

- організація побутового виживання;

- моральна та емоційна підтримка;

- захист та представництво сім'ї перед більш широким соціальним оточенням;

- організація відпочинку.

Нормально функціонуюча сім'я це сім'я, яка відповідально та диференційовано виконує свої функції, в результаті чого задовольняються потреби в зростанні та змінах як сім’ї в цілому, так 
і кожного іiі члена. Ледерер та Джексон вважають, що хороший шлюб характеризується наступними ознаками: толерантність, повага одне до одного, відвертість, бажання бути разом, подібність інтересів та ціннісних орієнтацій. А. Н. Обозова у своїх роботах говорить про те, що стабільність у шлюбі обумовлюється співпаданням інтересів та духовних цінностей партнерів та контрастністю їх особистісних якостей. Стабільності сім'ї сприяє також уміння членів сім'ї вести переговори. Повнота та благополуччя сімейного життя залежить від того, наскільки партнери можуть забезпечити виконання всіх сімейних функцій.

Вважаємо, що однією з головних причин сімейних негараздів може виступати неузгодженість у подружжі сімейних ролей, своїх сімейних обов'язків. Водночас можна стверджувати, що виникнення конфліктів спричиняе комплекс як соціальних, так і психологічних факторів.

Вивчаючи психологічні передумови, які призводять до розвитку конфліктних стосунків у сім'ях, ми дійшли висновку, що психологічний фактор є домінуючим, первинним та регламентуючим у характері подружніх взаємин. Результати досліджень свідчать, що перше місце займають психологічні причини, які складають загалом $70 \%$, тоді як соціальний фактор, а саме незадоволеність матеріальним становищем сім'ї, становить $30 \%$.

При детальному аналізі конфліктних ситуацій у сім'ях можна помітити, що в основі соціальних факторів простежуються психологічні чинники. Так, наприклад, конфлікти господарчо-побутового характеру в сучасних сім'ях пов'язані в першу чергу зі зміною уявлень про ідеальну модель ведення господарства: раніше жінки опікувались виконанням господарчо-побутової функції, а зараз прагнуть активної участі чоловіків у веденні господарства. Помітною стає тенденція, що чоловіки розділяють ідею рівноправності щодо ведення господарства, але неадекватність рольових домагань та очікувань призводить до непорозуміння та виникнення конфліктів.

Неспівпадання інтересів та поглядів - одна 3 найважливіших причин виникнення конфліктів, яка зумовлюється невмінням чи небажанням поступатися та враховувати бажання партнера. Б. Г. Херсонський до причин подружніх конфліктів відносить характер одного з членів сім'ї, а саме такі риси характеру, як емоційну збудливість, запальність, педантичність. На думку В. П. Левковича, психологічна та моральна незрілість партнерів зумовлюють виникнення труднощів у розвитку подружніх відносин.

Відзначимо деякі особистісні характеристики партнерів, які, на наш погляд, є першочерговими у розвитку конфліктних відносин у подружній діаді. Це егоцентричність, наявність акцентуації характеру, неадекватність самооцінки чоловіка чи дружини.

Егоцентричні риси характеру кожного з членів подружжя, їх концентрація на власному “Я” - один з факторів дестабілізації шлюбного життя. Подружжям частіше легше побачити егоцентризм свого партнера, ніж свій. У цьому сенсі слід звернути увагу на людей з вираженою акцентуацією. Акцентуація характеру - надмірна виразність окремих рис характеру, їх поєднання являє собою крайні варіанти норм, що межують з психопатіями, проявляються у внутрішніх та зовнішніх конфліктах, призводять до девіантної поведінки, мають тенденцію до переходу в патологічний стан. Вони накладають відбиток на особистість і на характер її взаємин з оточуючими. Залежно від рівня виразності акцентуйовані характери бувають явні і приховані та можуть переходити з одного в інший залежно від різних факторів: особливостей сімейного виховання, соціального оточення, професійної діяльності, фізичного здоров’я тощо.

Одна з головних якостей, від якої залежить успіх спільного життя - став- 
лення до себе, самооцінка і ставлення до партнера.

Самооцінка особистості, іiі рівень, адекватність - важливі фактори, що впливають на міжособистісні взаємини. Зокрема, показник адекватності самооцінки можна розуміти як співпадання (або розбіжність) між тим, як оцінює себе сама людина, і тим, як її оцінюють інші. [8] Це співвідношення формується протягом усього життя і складається під впливом багатьох факторів: суджень інших людей, реальних життєвих досягнень, оцінки досягнень інших тощо. Існують різні співвідношення цих показників. Розглянемо такі варіанти: об'єктивно висока оцінка (і оточення, i сама людина високо оцінюють індивідуальні якості); суб'єктивно завищена оцінка (оцінка оточення значно нижча, ніж самооцінка); суб'єктивно низька оцінка (людина оцінює себе значно нижче, ніж оточення); об'єктивно низька. Може бути також нестабільна самооцінка: іноді людина оцінює себе максимально високо, іноді вдається до перебільшеної самокритики.

Найбільш сприятливою є об'єктивно висока самооцінка: людина не тільки відчуває підтримку, позитивне ставлення партнера, але й має почуття власної гідності, самоповаги. Тому вона може дозволити собі поводитися природно, не намагаючись щохвилини доводити свою безумовну цінність.

Людина з неадекватно завищеною самооцінкою поводить себе менш природно. Усі іiі зусилля спрямовані на те, щоб зберегти високу самооцінку навіть всупереч реальним фактам. Якщо вона припускається помилок, то прагне довести, що це не іï провина. На думку Г. Навайтиса, людина із завищеною самооцінкою повинна постійно боротися, щоб інші теж цінували ії так само високо.

Об'єктивно низька самооцінка призводить до того, що людина втрачає бажання змінити ситуацію на краще.

Людина з неадекватно низькою самооцінкою найчастіше занижує свої можливості, відчуває себе ніякою серед інших людей, стримує свою активність у діях і міжособистісних контактах. Вона не може заявити про себе навіть тоді, коли іiі права регулярно порушуються, відмовити партнеру у його проханні, навіть якщо воно суперечить власним бажанням і поглядам. Людина 3 низькою самооцінкою вважає, що вона не заслуговує на кохання, на їі думку, більш значимої людини. Вона починає шукати в собі недоліки, а в партнері - нещирість. Людині з низькою самооцінкою властива тривожність, яка заважає знайти нові шляхи розв'язання власних життєвих проблем.

Підбиваючи підсумки, можемо відзначити, що аналіз динаміки, форм функцій конфліктної взаємодії свідчить про більш глибокий і складний характер іiі взаємозв'язку з особистісною динамікою в загальному процесі подружньої взаємодії. Зіткнення суперечностей між шлюбними партнерами на різних етапах подружнього життя, в разі їх конструктивного вирішення, можна розглядати як вагоме джерело зміни та формування самосвідомості сім'янина. У свою чергу формування адекватного самосприйняття кожного з партнерів, глибинний аналіз конфліктних ситуацій, високий рівень самокритичності, самопізнання та самоаналізу є передумовами ефективної саморегуляції та самореалізації в усіх сферах життєдіяльності, в тому числі у подружній взаємодії.

Таким чином, психологи та педагоги, з метою попередження виникнення руйнуючих конфліктних взаємин, повинні сприяти підвищенню психологічної культури молоді та дорослих людей, формуванню шлюбно-сімейних цінностей на нових засадах.

Також можна говорити про наступні перспективи досліджень:

- встановлення динаміки структури сімейних цінностей у лонгитюдному дослідженні пар;

- вивчення взаємозв'язку між образом “Я”, самооцінкою, рольовими 
сімейними цінностями та специфікою стосунків у шлюбі;

- дослідження гендерних відмінностей образу “Я” чоловіків та жінок та їх прояви у процесі подружньої взаємодії;
- розробка та апробація психологічного тренінгу та комплексної психокорекційної роботи, спрямованої на гармонізацію подружніх взаємин шляхом розвитку навичок сімейного спілкування, самопізнання, саморозвитку кожного $з$ партнерів.

1. Алешина Ю. Е. Цикл развития семьи : исследования и проблемы. //Вестник МГУ. Серия 14. Психология. - 1987. - № 2.

2. Алешина Ю. Е., Борисов И.Ю. Поло-ролевая дифференциация как комплексний показатель межличностных отношений супругов // Вестник МГУ. Серия 14. Психология. - 1989. - № 2.

3. Антонюк E. B. Становление ролевой структуры молодой семьи и ее восприятие супругами // Вестник МГУ. Серия 14. Психология. - 1993. - № 4.

4. Баздырев К. К. Как быть счастливым в браке. - М., 1987.

5. Витакер К., Бамберри В. Танцы с семьей. - М., 1997.

6. Обозов Н. Н., Обозова А. Н. Диагностика супружеских затруднений // Психологический журнал. 1982. - № 2.

7. Пірен М. Основи конфліктології. - К., 1997.

8. Семиченко В.А., Заслуженюк В. С. Мистецтво взаєморозуміння. Психологія та педагогіка сімейного спілкування. - К., 1998.

Abstract. TYPICAL CAUSES FOR CONFLICTS BETWEEN SPOUSES In this article we can see the typical reasons conflicts of formation in relationship on basis of psychological researches in the family. The author considers that psychologists and pedagogues have to promote rising of a psychological culture of youth and adults, forming of new family values. 